\title{
The Impact of Infectious Diseases on Kenya's Health Diplomacy; An Inter-State Phenomenon
}

\author{
Dr. Paul K. Kurgat \\ PhD; Senior Lecturer of Diplomatic History and International Relations; \\ Department of History, Political Science, and Public Administration - \\ Moi University, Eldoret, Kenya. \\ Dr. Alice J. Kurgat \\ $\mathrm{PhD}$; Senior Lecturer of Conflict Studies and International Relations; \\ Department of Development Studies - \\ Moi University, Eldoret, Kenya. \\ Dr. Thomas Otieno Juma \\ PhD; Lecturer of Political Science and International Relations; \\ Department of Social Sciences and Development Studies - \\ Catholic University of Eastern Africa; Nairobi, Kenya.
}

\begin{abstract}
The impact of infectious diseases is a real global phenomenon in the $21^{\text {st }}$ century buoyed by the accelerated pace of globalization which seem to dissolve the distinctions between; many domestic and foreign issues, regions and multinational actors, and even friendly and hostile states. The impact of infectious diseases on Kenya's health diplomacy calls for need to enhance public health partnerships to tackle such issues of international concern to effectively handle such diplomacy matters and timely. The study used qualitative study methodology by describing the context of Kenya's health diplomacy and employing available documents analysis. The study concluded that controlling emerging and reemerging infectious diseases require extreme actions and coordination between many national and international actors which Kenya and her international network of states must do through diplomacy.
\end{abstract}

Key Words: Kenya's diplomacy/ Health diplomacy/ Infectious diseases/ Global Health/ Foreign policy

\section{INTRODUCTION}

"The past most dangerous diseases have stirred inter-state relations as far as diplomacy is concerned. These include; The Black Death (Bubonic Plague), Smallpox, Severe Acute Respiratory Syndrome (SARS), Avian Influenza, Ebola, Leprosy, and Polio. In addition, some of the latest fears emanate from HIV/AIDs, Cancer, and now Corona Virus. The past experience has defined how health diplomacy ought to be conducted in face of infectious diseases."

The issue of infectious diseases ignores borders and races. It touches on public health and more so state relations and diplomacy. To combat these diseases, the international community and multi-lateral organizations must come up with public health conventions for policy formulations which are domesticated at the state level to initiate common front to fight infectious diseases. Formulation and documentation of international health regulations for infectious diseases control involves good inter-state relations and shuttle diplomacy by all stakeholders. 
Historically, health has occupied the lower echelons of national priorities. However, national policy makers have increasingly recognized the impacts that health crises may have on national interests. As a result, particular health issues occasionally have been elevated with national agendas, especially if they have implications for foreign policy and diplomacy and/or they are perceived as threats to national security.

Controlling emerging and reemerging infectious diseases can require extreme actions and coordination between many national and international actors. Practitioners and policymakers alike who might once have advocated international health programs now speak of global health. The increased number of commitments to global cooperation in public health surveillance and response have placed new demands on international institutions and legal instruments and required new agreements between and among nations. As nations integrate health into their broader foreign policy strategies, traditional population health concerns join other goals, which in turn create the need for new resources. Stakeholders look to global health diplomacy as a means to accomplish a variety of outcomes, from the aspirational to the purely pragmatic. One result is the larger number of health actors. To counter the effects of disease burdens on economic development, wealthy donors have dramatically increased their willingness to pool and project resources for health. Indeed, the outpouring of new health assistance from governments and philanthropists over the last decade has set the stage for major new public-private partnerships and global health initiatives, a profusion that has elicited calls for more formal global health governance (Katz, Kornblet, Arnold, Lief, and Fischer, 2011).

Identifying health issues as having an impact on diplomacy of a country may lead to higher prioritization and more attention from top policy makers, in turn, bringing greater political support and more funding. It is worth noting that characterizing health issues as a national priority may change the understanding of a health threat, and put more emphasis on the views of those outside the health community and potentially change the approach to solving the problem.

However, the decision on which health issues should be given priority on the foreign policy and diplomacy agenda contribute to overall improvement in diplomatic relations, which may enhance inter-state relations.

\section{ENVISAGED PROBLEM IN HEALTH DIPLOMACY}

The latest decades of contemporary international relations is characterized by many dilemmas from security to economics and health. Though health has been peripherally situated from mainstream issues in Diplomacy, it has in fact featured prominently in inter and intra state politics to affect how states relate, transact with one another, and perceive each other in the Neoliberalist and Realist world. Some states have established positive steps in their health diplomacy to show their seriousness to this issue hence easier to measure impact of infectious diseases on their diplomacy. On the other hand, it is not clear what the impact of infectious diseases is on Kenya's diplomacy. It is this gap that propels the study to examine the existing state of affairs.

\section{METHODOLOGY EMPLOYED}

This study set off to use qualitative study methodology involving describing the context of Kenya's health diplomacy in relation to impact of infectious diseases and the existing practice of health diplomacy operational application. Available documents were also analyzed. 


\section{EMERGING AND RE-EMERGING DISEASES AND FOREIGN POLICY: AN OVERVIEW}

In an attempt to understand the relationship between foreign policy and public health, this paper will ask Youde's (2005) question that is whether there is a relationship that exists between the health of individuals within a state and that state's national security. a question that has received increased attention in recent years in the wake of (Acquired Immune Deficiency Syndrome (AIDS) pandemic, Ebola, Hantavirus, SARS, anthrax, and Avian flu. Numerous policymakers and academics have called for a redefinition of national security to include health threats. Security should be interpreted as both relational and independent for "individual national securities can only be fully understood when considered in relations both to each other and to larger patterns of relations in the system as a whole" (Buzan, 1991: 1920).

Fidler (1998) argues that there is need to examine emerging infectious diseases not only as public health and scientific problem, but also as an international political problem and, therefore, the need to analyze emerging infectious diseases from the perspective of international politics and its challenge to international relations. What Fidler refers to as "Microbialpolitik". According to him the interaction between the two "produces two important dynamics: (1) the effect infectious diseases have on international relations, and (2) the effect international relations have on the nature and spread of infectious diseases" (ibid:5).

Infectious diseases are caused by pathogenic macro organisms, such as bacteria, viruses, parasites or fungi; the diseases can be spread, directly or indirectly, from one person to another. Zoonotic diseases are infectious diseases of animals that can cause disease when transmitted to humans (WHO, 2013). Infectious disease is a pathological condition spread among biological species, although varied in their effects, are always associated with viruses, bacteria, fungi, protozoa, multi-cellular parasites and aberrant protein known as prisons. Scholars, addressing issues of infectious diseases see communicable diseases in the context of public health (Klempner \& Shapiro, 2004).

As the world loosen up from the grip of the Cold War rivalry, international relations and national security analysts have begun to embrace concepts of human security and preventive defense arguing that factors such as environmental degradation, resource scarcity, and overpopulation now pose more significant threats to global security. Adding to these threats is the proliferation of emerging (EIDs) and re-emerging (REIDs) infections on a global scale (Price-Smith, 1999). The processes of globalization have altered traditional health given the fact that the many interactions and exchanges infringes upon a sovereign state's ability to control what occurs in its territory. Indeed EIDs and REIDs have made the globalization of public health a permanent feature of international relations.

Globalization creates challenges for the governance of global health, including the need to construct international regimes capable of responding to global threats to public health. These problems are, however, not new. The globalization of public health led to the development of international health diplomacy and international regimes for public health beginning in the mid- 19th century (Fidler, 2001). International health diplomacy began in 1951, when European states gathered for the first International Sanitary Conference to discuss cooperation on Cholera, Plague, and Yellow Fever. These states had dealt with transboundary disease transmission through national quarantine policies. The next 100 years witnessed an evolution in international cooperation on infectious diseases. States convened conferences, adopted treaties, and created several international health organizations to facilitate cooperation on the control of infectious diseases. By the end of 1951 this scientific and diplomatic process had produced the World Health Organization (WHO). Over the course of a century, the global threat 
of infectious diseases had produced processes, rules, and institutions for global health governance.

The processes of globalization have collapsed the demarcation between the national and international health and undermined the ability of the sovereign state to protect the public from infectious diseases. Heymann aptly put:

Now more than ever, no country is an island. No country can fortify itself against an invasion of infectious diseases either from its neighbours of from the remotest corners of the globe (Heymann, 2001:13).

In an era of unprecedented human movement and interaction, the trans- border mobility of humans, animals, food, and feed products increases and so, is the spread of infectious diseases. The resurgence of Malaria, the AIDS pandemic and global spread of the annual influenza virus further illustrate how vulnerable nation- States are in today's globalized society. However, the burden is greatest for developing world. Indeed, whether, carried by unknown traveler or an opportunistic vector, human pathogens can rapidly arrive anywhere in the world.

This paper agrees with Fidler (1997: 13) that: " the globalization of public health represents, therefore, not only a medical and scientific challenge for physicians and public health officials, but also a challenge to the conception of citizenship, the state, international relations, and humanity itself ". EIDs are some of the problems facing states that are beyond their sovereign control and require international cooperation to address. According to the World Health Organization Report (1996:321), IEDs represent a "global crises" that require concerted efforts from the world community. Indeed, pathogenic microbes may ignore borders, but they do not move around the globe without having effects on international relations (Fidler, 1998:5).

When considering the international aspects of infectious diseases, one must recognize that non-governmental organizations, multinational corporations, and even individuals can influence events. I have argued...in international relations terms, pathogenic microbes constitute nonstate actors with transnational power. Even so, the impact of such nonstate actors, including pathogenic microbes, continues to be filtered largely through the policies, ambitions, and fears of the state (ibid: 7)

Human demographics and behaviour, technology and industry, economic development and land use, international travel and commerce, and breakdown in public health are explicitly social in nature and the microbial adaptation and change is partly the result of social behaviour and social change (Meyer, 2006). However, social scientists have been minimally involved in research on emerging diseases, incorporated into epidemiologic, public health, or infectious disease research and policy on emerging infections.

The emergence and international spread of such diseases like Acute Respiratory Infection (SARS) and the Avian Influenza Virus (H5N1) clearly underscored the vulnerability of both developing and industrialized countries to emerging and re-emerging infectious diseases and demonstrated the porous nature of national borders, eroding in some instances traditional nations of state sovereignty (Heymann \& Rodier, 2004). Heymann, (2005) observes that in a closely interconnected and interdependent world, the repercussions of adverse events easily cross border to intrude on state affairs in ways that cannot be averted through traditional military defences. 
Infectious disease know no national boundaries, states must develop and implement effective international cooperation and collaboration in these programs. Only by knowing what is happening to state's neighbours can it predict what will happen to them. Fortunately, effective prevention and control of epidemic infectious diseases can be achieved by building global public health infrastructure, and by developing international surveillance and information exchange programs. New diseases such as Ebola and other viral hemorrhagic fevers, is probably the most frightening. Their natural history is unknown, and our understanding of the factors responsible for, or contributing to their emergency, and how they interact, is incomplete. The need, therefore, is for expanding research on infectious disease agents, their evolution, and the vectors of disease spread and methods of controlling them, and vaccines and drug development (Gubler, 2001).

The problem of infectious diseases has gone beyond the prerogative of states. There is a growing importance of multinational corporations and Non governmental organizations on both global health problems and governance (Willets, 1997) since infectious diseases poses both internal and external challenges.

Globalization creates challenges for infectious disease policy. These challenges constitute problems that arise between states from global microbial traffic. Vertical challenges, such as inadequate surveillance capacity, are problems countries face inside their territories that requires responses within states. States cannot handle horizontal or vertical challenges without cooperating with each other. Unilateral efforts have limited impact when the source of the problem is beyond national jurisdiction (Fidler, 2003).

Although Microbes bypass the trappings and substance of sovereignty, their movements nevertheless, do not change the structure of international relations because states remain the primary actors, albeit weakened ones. After all, the preservation of society from disease still is the fundamental duty of the government (Fidler, 1998).

Gathura in a "Health Watch" stated that malaria vaccine on trial in Kenya would cost the country upto sh 3.7 billion estimates of Kenya Medical Research Institute. In another journal MDM Policy, the practice estimated the cost of such implementation dubbed RTS in Burkina Faso, Ghana, Kenya, Mozambique, and Tanzania considered Kenya's case comparatively expensive. The high cost in Kenya is attributed to higher salaries paid to health workers. The point is not really what malarial vaccination would cost and where but rather the impact of the cost to the country and much more being an issue of diplomacy involving crosscutting country interests (Gathura, 2020a: Jan.).

In a separate report (Gathura, 2020b: Jan.), The WHO data shows hundreds of Kenyans including children continued to suffer from highly preventable diseases including measles and kala-azar. Some of these were reported in West Pokot, Turkana, , Nyeri, Kirinyaga, Garissa, Kajiado, and Dadaab refugee camp. Director of Medical Services Mr Kioko called for reactivation of Multi-Sectoral Outbreak Management which in specific would call for inter-state collaborations and linkages with vital relevant Non-State Actors. The UN however, observes Kenya being on track to meet its health targets towards Vision 2030 even though it needs colossus sums of money to achieve this.

\section{A BRIEF OVERVIEW OF GLOBAL GOVERNANCE OF INFECTIOUS DISEASES}

The cholera epidemics in Europe between 1830 and 1847 spurred international diplomacy. The International Sanitary Convention that dealt with cholera was adopted in Venice, Italy, in 1892, followed by another convention that dealt with plaque in 1897 (World Health 
Organization, 2002). The global public health governance is delegated to the International Health Regulations (IHR) for infectious diseases control and dates back to the First International Sanitary Conference in Paris, France in 1951.

The international community established multilateral institutions to enforce these conventions. American states set up the International Sanitary Bureau (ISB) in 1902, which became the Pan American Sanitary Bureau, a precursor to the Pan American Health Organization (PAHO). PAHO agreed to serve as World Health Organization (WHO)'s regional office for the Western Hemisphere in 1949 (WHO, 2003). The Health Organization of the League of Nations (HOLN) was formed in 1923 between the two World Wars. Article xxiii of the League of Nations Covenant stated that members would "Endeavour to take steps in matters of international concern for the prevention and control of disease" (League of Nations, 1923).

The global governance of emerging infectious diseases was transformed with the establishment of Article 55 of the UN Charter which states that a primary objective of the UN is to promote "higher standards of living and solutions of international...Health" on July 22, 1946 (Fidler, 2003: 485-505), at the International Health Conference in New York. In New York, representatives of 61 countries signed the WHO Constitution that came into force on April 7, 1948 (Arai-Takahashi, 2001). The preamble states that its principles are basic to the happiness, harmonious relations and security of all people, "thus expressing a universal aspiration" (Grad, 2002: 981-982). According to Article 19 and 23 the WHO constitution grants to the agency power to seek member states adoption of the conventions, promulgate regulations and make recommendations (Taylor, Bettcher \& Fluss, 2002). However, member states retained sovereignty, without burdensome requirements to upgrade their domestic surveillance and sanitary systems. Infectious disease policy require governance responses between governments' response that focuses on interstate cooperation to minimize disease exportation and importation and strategies that reduce disease prevalence through improved domestic public health. Indeed, the "state is the key actor in infectious disease governance" (WHO, 1996: V).

\section{KENYA'S PUBLIC HEALTH POLICY ON INFECTIOUS DISEASES AND CONTROL}

To control and prevent the spread of contagious diseases from across the border, the Kenyan Government has put in place some legal notices on rules and regulations for guidance.

Part 4- Ports and Inland Borders of Kenya Notification of Infectious Disease or Death on Board of Vessel: L.N 41/1970

1. The provisions of this Act in respect of the notification of the occurrence of cases of infectious diseases in man, or sickness or mortality in rodents or other animals susceptible to plague, shall apply to every vessel at any port or place in Kenya, but, wherever it is therein required that notification be made to the health authority, or medical officer of health, such notification shall be made to the port health officer.

2. No fee shall be payable to any ship surgeon or other medical officer of a vessel or shipping company in respect of the notification of any case of infectious disease on board of any vessel.

3. It shall be the duty of the master to report to the port health officer of any person who has died from any cause whatever on the vessel during the voyage just complete, or while the vessel is in port, and also the cause of death (Republic of Kenya, 1970).

4. The port health officer may, at any time board any vessel and inspect any part thereof or anything therein, and may medically examine any person on board and require, any 
such person to answer any question for the purpose of ascertaining whether or not infection exists or has recently existed on board.

5. Any such person who refuses to allow any such officer to board any vessel or to make any inspection, or medical examination as aforesaid, or otherwise obstructs or hinders any such officer in the execution of his duty, or who fails or refuses to give any information which he may lawfully be required to give, or who gives false or misleading information to any such officer knowing it to be false or misleading, shall be guilty of an offence and liable, to a fine not exceeding two thousand shillings (Republic of Kenya, 1970).

6. According to Notification to Medical Officers at Ports L.N. 41/1970, upon the occurrence on any vessel of any case of death from any notifiable infectious disease, or of such other disease as the minister may prescribe, or of any sickness or mortality among rodents or other animals on any vessel or within the harbour area suspected to be due to any formidable epidemic disease, the port health officer shall forthwith inform the medical officer of the health of the area in or adjoining which the port is situated of the occurrence and the measures taken or intended to be taken in connection therewith (Republic of Kenya, 1970).

In the case of any vessel having, or suspected on reasonable grounds of having on board in any person, animal, or thing the infection of any infectious disease, the port health officer, acting in accordance with instructions and with rules made under this part, may grant or continue pratique to such vessel subject to such conditions or restrictions as may be deemed necessary, or if he deems it necessary so to do, may withhold or withdraw pratique and place the vessel in quarantine. When such measures are taken the port health officer shall immediately report, by telegraph or other expeditious, the action taken by the officer and the reasons therefore to the Director of Medical Services and the nearest Medical Officer of Health (Republic of Kenya, 1970)

7. The Declaration of Infected Places, Ports of Entry of 28 of 1961, the Minister may, by order

a) Declare that any place beyond or within Kenya is infected with a formidable epidemic disease or that a formidable epidemic is liable to be brought or carried from or through that place, and thereupon, and for so long as order remains in force, that place shall be proclaimed place within the meaning of the act.

b) The act prohibit, restrict or regulate the immigration or importation into Kenya of any person, animal, article or things likely, in his opinion, to introduce an or regulate the immigration or importation into Kenya of any person, animal, article or things likely, in his opinion, to introduce any infectious disease, or impose restrictions or conditions as regards the examination, detention, disinfection or otherwise of any such animal, article or thing.

c) States that any person who contravenes or fails to comply with an order made under sub-section (I) shall be guilty of an offence and liable to a fine of not exceeding two thousand Kenyan shillings (Republic of Kenya, 1970).

Where a vessel has been placed in quarantine at any port or place in Kenya, the minister may for the purpose of more effectually dealing with the infection on board, require the master thereof to remove such vessel, at his own risk and expense, to any other port or place outside the territorial waters (Republic of Kenya, 1970).

The act further gives direction on how patients should be handled. It states that where any person on board of any vessel is suffering from any infectious disease or other disease and in the opinion of the port health officer, is not accommodated or is not being nursed or treated in such manner as guard adequately against the spread of disease or to promote recovery, the 
port health officer may cause such a person to be removed to a hospital or place of isolation on shore and there accommodated and treated for such period as may be considered necessary in the interests of the patient or to prevent spread of infection. All reasonable expenses necessarily incurred in dealing with a patient under this section shall be a charge against the master or agent of the vessel, and may be recovered from either the master, argent or both of them by the government (Republic of Kenya, 1970).

Where any person on board of any vessel is believed to have been recently exposed to the infection, and may be in the incubation stage of any notifiable infectious disease the port health officer may require such person to remain on board such vessel, or alternatively to land and proceed direct to his place of destination and there report himself to the medical officer of health for medical surveillance by such medical officer of health until considered free from infection. In a case where in the opinion of the port health officer any such person cannot otherwise be kept under medical surveillance or the public health cannot be otherwise safeguarded, such a person may be removed to a place of isolation on shore and there detained until considered free from infections.

Thereafter the Port Health Officer shall notify to the medical officer of health of the district in or adjoining which the port is situated, and to the medical officer of health of the district where such person's place of destination is, that such person is believed to have been recently exposed to infection and has been allowed to land and proceed to his destination. Any person who refuses to comply with, or willfully obstructs the execution of this section of the act shall be guilty of an offence and liable to a fine not exceeding one thousand Kenyan shillings or to imprisonment for a term not exceeding three months or to both (Republic of Kenya, 1970). In case of death on board of any vessel at any port or place in Kenya, it shall be the duty of the master of such vessel to cause such a body to be properly buried; any reasonable and necessary expenses thereby incurred may be recovered by the master from any person legally liable for the same (Republic of Kenya, 1970).

According to the Powers to Enforce Precaution at Frontier 28 of 1961, when it is considered necessary for the purpose of preventing the introduction of infectious disease into Kenya, the minister may, by order- regulate, restrict, prohibit the entry into Kenya at inland borders, or any other part thereof of any persons, or of persons specified class or description or from any specified locality or area ; regulate, restrict, or prohibit the introduction into Kenya at its inland borders, or any specified part thereof, any animal, article or thing (Republic of Kenya, 1970).

It is clear from the articles cited in the Public Health Act that if well implemented it can prevent the spread of infectious diseases from one continent to another, region and even internally. However its emphasis on alerts at major ports overlook cross border human, animal, goods and other services traffic. The high road traffic within the region is a challenge to curbing infectious diseases. Furthermore, the boundaries are porous and communities living along the borders do not always use the designated official entry and exit points.

The interdependence of international system and international society in dealing with infectious disease control also means that the national interest of a state is interdependent with international society in dealing with pathogenic microbes. In this regard international law joined domestic law as a tool of infectious control. 


\section{THE FOREIGN RELATIONS AND DIPLOMACY OF INFECTIOUS DISEASES}

Nakajima (1947) states that it has been established that many deadly diseases, once considered to be indigenous to the tropics may be and are carried to the temperate zones (infectious) by various means and transmitting agencies..., hence each nation to some degree must become the keeper of its brother nations, this as a matter of self-protection if for no other reason. Plague was deadly to Asia reached Italy in 1347 (Black Death), and others such as cholera and yellow fever have over the years influenced foreign policy. The threat of epidemics has prompted national governments to take collective action to protect their population. Taylor (1996) confirms that "fighting disease and fostering development are a challenge to states' foreign policies.

Globally, the coronavirus was confirmed in the Chinese city on January 7, 2020. Cases have since been confirmed in several other Asian countries, Europe and the United States. The World Health Organisation, WHO, has since declared it a public health emergency of international dimensions. WHO chief Tedros Ghebereyesus said whiles China had a robust health system to detect and control, his outfit remained concerned about the virus entering country's with weak systems. Almost all African governments have publicly put in place strict screening at points of entry especially airports. Ivory Coast, Kenya, Ethiopia and Botswana have recorded suspected cases. All except Botswana have reported that the tests were negative. African airlines have cancelled scheduled flights to China except for Ethiopian Airlines (Mumbere, 2020: Jan.).

The latest scourge of deadly infectious disease that threatens the globe from China - the Corona Virus, has stepped in to confuse very good relations that the Eastern Tiger state has enjoyed especially in Africa and for this case, Kenya. This is understood from the massive governmental projects in dealership with China. The reaction has forced certain steps due to fear.

Infectious diseases are serious issues to states in the contemporary globalized world. Kirkpatrick (2020: Jan.) point, the Trump administration is imposing temporary travel restrictions that bar entry into the United States by any foreign national who has traveled to China in the past 14 days, officials said Friday. The restrictions, a reaction to the coronavirus that has been declared a public health emergency by the World Health Organization, will be put into place at 5 p.m. on Sunday. The United States on Friday also declared the coronavirus, which has sickened nearly 12,000 people and has spread to the United States and other countries, a public health emergency.

Anonymous (2020: Jan., 31) in Aljazeera confirmed that The United Kingdom has confirmed its first two cases of the new coronavirus, a day after the World Health Organization (WHO) declared the outbreak a global emergency. At least 213 have died in China, as more countries announced plans to evacuate their citizens from Wuhan, the Chinese city at the centre of the outbreak.

Merab (2020: Jan.,27) reports, The Foreign Affairs ministry has advised Kenyans against all but necessary travel to China as a precaution, following the quick spread of a virus that has left at least 81 people dead so far. In a statement on Monday, Principal Secretary Macharia Kamau emphasised the warning in the case of Wuhan, the epicentre of the new coronavirus. The deadly virus that has prompted travel restrictions in China is sending shockwaves throughout Asia's tourism industry, which has become increasingly reliant on growing numbers of Chinese visitors. 
International travel, commerce and war have historically been the great channels for the global spread of infectious diseases (Dorolle, 1968; Wilson, 1995; Fidler, 1997, 1998). Many outbreaks have reminded us of the disruption of travel and commerce that can occur when local outbreaks have global implications. As early as 1866, experts were arguing that the traditional strategy against the importation of infectious diseases- quarantine- was no longer an effective policy given the growth of international trade and travel. As Fidler asserts "infectious disease measures historically have served as demarcations by which "we" protect ourselves from the diseases of the "others". In a context of a globalized world of travel and trade in which humans, insects, animals, animal products, and food travel far and wide, clearly demonstrate that geographic borders cannot stop the spread of infectious diseases (PriceSmith, 2001).

Unjustified reactions to the emergence and re-emergency of infectious that may take the form of trade barriers, restricted travel and decreased tourism hurts not only the economy but interstate relations if it is a position taken by one party. The resurgence of infectious diseases imposes other costs as well. The response to an outbreak requires an immediate investigation followed by extensive containment activities, at times placing great financial demands on countries and calling to halt routine measures for the prevention and control of other important diseases. The economic costs of an outbreak with widespread and sensational reporting can be immense.

Travel- related illness may give rise to public health concerns that precipitate a disastrous fall in tourist revenue. Following the death of a single British tourist from Malaria, an estimated 101000 UK tourists either cancelled or postponed visits to Kenya over the next two years costing the country approximately UK Pounds 69 million in foreign earnings or around 33\% of its health budget. Efforts to prevent travel- associated diseases may thus produce significant economic benefits to host countries (UNICEF, UNDP, WB, WHO, 2004).

Migrant populations, especially refugees are among the most vulnerable to emerging infectious diseases. In Kenya, infectious diseases, such as multi- drug resistant TB and Polio are frequently linked to the massive influx of immigrant refugees from neighbouring countries in internal conflict. Communal conflicts are characterized by massive dislocation of populations and extensive destruction of infrastructure. Refugee populations are the most vulnerable to emerging infectious diseases, even more so than other migrants. Refugees' health in particular is complicated by the inability to track refugee departures, transit times, and arrival accurately, making it difficult both to acquire prescreening information and to transmit that information to government resettlement programs before refugees report for post- arrival screening.

Countries subject to civil war or social unrest often find themselves vulnerable to increases in infectious diseases. Disease knows no borders and end up crossing borders and re-emerging in neighbouring states with refugees fleeing conflict in their states. Re- emergence of polio and the rise of tuberculosis in Kenyan borders are argued, exacerbated by the influx of refugees from her neighbours that have been having civil wars. Cooperation across borders is the most logical places to initiate efforts.

The response to an outbreak of infectious disease is primarily a domestic government function. Maintaining the capacity to respond to a plethora of pathogens is a costly goal for governments. Recognizing that pathogens do not respect political borders, international resources are made available to help combat infectious diseases with the aim of minimizing negative health impacts in a specific country as well as preventing further geographic spread. 
However, international organizations such as the World Health Organization (WHO) have limited ability to respond to outbreaks of infectious disease without explicit invitation by the local government where an outbreak occurs. As such, a government is responsible for addressing domestic public health challenges but is forced to recognize and publicly admit when capacity is insufficient and international assistance is necessary. "Achieving this balance of domestic sovereignty over health issues and international responsibility to prevent further transmission is challenging and requires effective domestic governance" (Prescott, 2007:2).

The Draft HIV/AIDS Prevention and Control Bill, 2002, clause 13, prohibit against compulsory testing for travelers into and out of Kenya (Daily Nation, 2002). Clause (ii) on prevention of Transmission states that, "A person who is and is aware of being infected with HIV or who is carrying and is aware of carrying HIV antibodies, shall not knowingly or recklessly, place another person at risk of becoming infected with HIV, unless that other person knew that fact, and voluntarily accepted the risk of being infected (Daily Nation, 2002). Clause 33(I) on Restriction on Travel and Habitation states that "A Person's freedom of aboard, lodging, or travel within or restricted on the grounds only of the person's actual, perceived or suspected HIV status (Daily Nation, 2002).

Youde (2005: 198) observes that at the end of 2002, UNAIDS and the WHO estimated that 42 million people worldwide were infected with HIV. Of these 42 million, roughly 29.4 million HIV positive people lived in sub- Saharan Africa, a figure that represents $70 \%$ of all infected people worldwide. Moreover, these 29.4 million HIV positive people represent $8.57 \%$ of the total population of Sub-Saharan Africa. At the 2000 Abuja African Summit on Rollback malaria, African leaders resolved to initiate appropriate and sustainable action to strengthen health systems. They reflected on the convergence of political momentum, institutional synergy and technical consensus on malaria and other infectious diseases. Health issues have been incorporated as part of the integration tenets in Africa. African leaders are advancing a continental vision for integration that includes enhancing trade and transportation, promoting stronger collaboration among Africa's Regional Economic Communities (RECs), and promoting accountability through bodies such as the African Review Mechanism and AIDS Watch Africa (AWA), and AFRO Advisory Committees of Experts on Malaria and TB (African Union, 2012). The African states partner with the UN through the UN Special Initiative for African Development that deals with health sector reform and disease control (WHO, 1996).

Several scholars have embraced the human security paradigm in influencing state's security (Garret, 1994, 1996; Price- Smith, 2001; Thomas and Tow, 2002). It is asserted that high rates of infectious disease can have severe consequences for a state's economy, educational system, military, and political institutions. Demands from infectious diseases divert government expenditures away from investments in education, roads, water supply, and other factors that foster economic activity toward consumption, thereby, undermining the foundations of economic growth (Lewis, 2001). Cultural, political, economic factors and, historical experiences combine to weaken infectious disease control in developing countries. Furthermore, globalization weakens the state's power to respond to social, economic and environmental problems and reduces the policy flexibility of the government to devote more resources to public health by complicating fiscal and budgetary conditions (Nieto, 2005).

\section{PUBLIC HEALTH POLICY AND COLLABORATION ON INFECTIOUS DISEASE CONTROL}

Public health can be defined as a multi-disciplinary profession that tries to promote health by preventing diseases hence prolonging life. The multi-disciplinary profession includes medical sciences, blending it with a bit of engineering, law, and teaching methodology to educate people about health. Public health education is conducted through sanitation thus the science 
which tries to remove or eliminate factors that prove to be harmful to human health. Furthermore, health is like a mother concerned with eight primary health care, namely; the treatment of simple ailments like malaria, typhoid, to name but a few. Treatment of the sick is one way of preventing the spread of such diseases. Therefore, included in the primary health care are nutrition, water supply, housing and sanitation, pre-natal and ante-natal health care. Included in the later are family planning and immunizations.

According to a Public Health officer in Uasin-Gishu District Mr. Muyonga (Personal communication, October 15,2004 ) public health education is mainly conducted by the Ministry of Health through organized programmes from the grassroots to the national level. There are committees from the village, location, and district, provincial and national levels whose main responsibility is to look into the health issues within their jurisdiction by educating the community. The committee members include women groups, the youth, house helps among others. The Ministry mobilizes the groups so as to achieve their goals, thus preventing the spread of diseases and prolonging life.

In International level, the government of Kenya is also taking care of public health in relations to infectious diseases such as Meningitis, Malaria, HIV/AIDS, SARS, Ebola, Tuberculosis (TB) from across the border; this means preventing the transmission of contagious diseases from one country to another. Let us now look into the diseases one by one and find out the role that has been played by the Kenyan governments in preventing and eradicating such diseases.

In August 2002, there was a claim that Meningitis outbreak in Rwanda had spread to Nyanza Province in Kenya. This followed the report that nine patients had been diagnosed with the disease and were confined at the Kisumu District Hospital. Dr. Otieno Opondi, the Hospital Medical Superintendent said the patients had been isolated to prevent further spread. Another doctor, Dr. Misore said the Health Ministry's disease surveillance unit was working with the hospital to detect any cases. The doctor said health personnel had been told to conduct "double tests" on Malaria patients and screen for traces of Meningitis. People were given precautions that the symptoms of the two killer diseases include headaches, weak limb joints, fever, and vomiting, were similar, making it difficult for health personnel to manage them (Daily Nation, 2009).

A group of people from Western Province of Kenya went to Gullu in Uganda for a celebration. When they came back they were put in isolation and isolation and monitored for some time by Medical Health Officers. This was in June, 2002. Those people were suspected of having contracted Ebola. This kind of infection often begins with fever, headaches, fatigue and diarrhoea making the initial diagnosis difficult because the symptoms are similar to those of other diseases in an impoverished area where health care is poor. Death sometimes accompanied by massive internal and external bleeding can follow within a week. It is known to have killed up to $90 \%$ of the victims. The epidemic is linked to eating of ape meat especially in Congo (Daily Nation, 2002).

Malaria is a vector borne disease that the Kenyan government is trying to fight from across her borders. This ailment is transmitted by female anopheles mosquitoes which is a tiny creature causing havoc to the health system. Malaria is passed on to humans from a bite of an infected female mosquito. When a mosquito bites a person it passes on a parasite called plasmodium which lives and breeds in the mosquito's stomach into the human blood stream where it is carried to the liver and eventually multiple. Several health, political and economic networks have developed throughout the region, and these, in turn, have encouraged more cross-border 
cooperation efforts to prevent and control the emergence and spread of infectious diseases. Kenya is also a signatory to the 1998 Global Initiative, the Roll Back Malaria Campaign, to eliminate the Malaria burden, by the year 2030.

The Roll Back Malaria is a component of the Board of Global Fund to fight AIDS, tuberculosis and Malaria. The Kenyan Government received 510 million Shillings from the British Government to help fight Malaria. Experts, locals and malaria patients interviewed, blamed lack of an effective public health policy for the intermittent outbreak of the vector borne diseases (Daily Nation, 2002)

Some international organizations are involved in malaria campaign in Kenya. For example African Medical Research Foundation (AMREF) has been supplying anti-malarial drugs to prone areas like Kisumu District and other areas. United Nations Children Education Fund (UNICEF) issued a bulletin in which it spells out ways of taming the diseases. The home based management approach is a simple and effective initiative that has revolutionized the treatment of malaria, putting knowledge and essential drugs into the hands of those who need them most. UNICEF works closely with World Health Organization (WHO) and other Roll Back Malaria partners to support governments and communities in the campaign against malaria.

When the African Heads of State met at Abuja in April 2000, they declared war against malaria. They committed themselves to an intensive effort that would see deaths from halved by 2010 through the implementation of the strategies of WHO Initiative, Roll Back Malaria. Kenya's National Malaria Strategy (NMS) is the country's response to the Abuja Declaration signed by 37 countries (Ibid) NMS guarantees people access to quick and effective treatment. It would also ensure the availability of treated nets and other vector control measures were available to communities.

\section{THE CASE OF HIV/AIDS}

This section will discuss HIV/AIDS because of its national impact; its potential economic impact in Kenya, and because of the variety of approaches that have been developed to combat the illness. In 2000, the United Nations Security Council held a special session devoted to AIDS and its challenge to international security- the first time that a public health issue had received such attention from the world's body. Therefore, to describe infectious diseases control as a national interest means that the state believes that infectious diseases represent a threat to values and interests important to that polity for domestic and/or international reasons (Fidler, 1998). States like Canada and Denmark have explicitly included issue of health security and human security in their national foreign policies (Youde, 20005: 193). As Fidler puts; "the effects of globalization have undermined that ability of sovereignty states to protect their citizens from emerging infectious diseases in the conventional way" (Fidler, 1997:1).

Ancient Egyptians and Indians thought pestilences were punishments inflicted on humans by supernatural beings as retribution for "wicked" behaviour. The myth surrounding HIV/AIDS dominated international relations and diplomacy for quite some time. British virologist John Seale even argued that it was artificially created in North America as a weapon of germ warfare (Ogot, 2004). Professor Wangari Maathai, a trained biologist and an Assistant Minister for Environment and Natural Resources then, argued without concrete evidence in support of the idea that it was manufactured as a biological weapon to wipe out the black race from developing countries (East African Standard, 2004).

Speculation as to the origin of AIDS continued in the 1980s. Jane Teas of the Harvard School of public Health wrote to the Lancet medical journal and argued that AIDS is a variant of African 
swine fever and that AIDS virus could have emanated from a local person who eats undercooked swine flesh passed it to an American tourist during a sexual encounter (Ogot, 2004).

Dr. I.C Bybjerd of Denmark's Department of Communicable and Tropical Diseases argued in the Lancet journal that AIDS was a tropical disease. In 1984 Dr. Kevin de Cock in an article submitted to the British Medical journal disputed the Haitian connection and the notion of a tropical disease, posing a question as to it was not spread to the neighbouring Dominican Republic. He came up with the theory of African connection-that it had existed undetected (ibid).

At the International Symposium on African AIDS held in November 1985 bitter row between American and European scientists claiming that the disease originated from Africa. This was a big threat to lucrative tourism and fear of bad publicity had caused several countries, including Kenya, to put pressure on scientists working there to remain silent. Prof. Robin Weiss, of London Institute of Cancer Research warned: African governments cannot pretend that AIDS does not exist. Any country that ignores the disease in the hope that it will go away is making its people hostage to suffering (ibid).

In Kenya, the disease was perceived as a disease of prostitutes, promiscuous people and an urban disease. In the African continent Kenya and South Africa were cited in the diplomatic circles in the 1990s as countries that lack effect therapies for HIV/AIDS and stigmatization of the people associated with opportunistic infections. The government policy was characterized by denial and rejection of any kind of comprehensive programme of intervention against HIV/AIDS. These observers think was quite diplomacy to cushion tourism industry. This was a diplomatic and foreign policy strategy to protect tourist industry a source of foreign currency and promote Kenya as a holiday destination. In May 1985, Dr. James Else, Director of the Institute of Research (IPR), National Museums of Kenya, linked the Vervet monkey, commonly found in Kenya, to a virus thought to be the cause of AIDS- the anti-bodies HTLV-3 and submitted a grand proposal to the European Economic Community (EEC) for in-depth funding (ibid). The African connection of AIDS tried to identify Kenya as a possible epicenter and was extensively quoted by the international media. In the Scandinavian country of Sweden television programmes claimed that ten per cent of Kenya's population suffered from AIDS and was second to Congo in the continent's HIV/AIDS cases (Ogot, 2004).

In what seemed to be a major foreign policy statement and a diplomatic onslaught President (Rtd) Daniel arap Moi termed the television programmes a malicious campaign waged abroad by those envious of the peace and prosperity Kenya had enjoyed since independence. He urged Kenyans to ignore what he called "AIDS gossip" (ibid). The question asked in Kenya's Foreign Service was "must there be an African connection for every disease?" many disease, as is historically documented including Syphilis, were imported into Africa from other continents.

On 15th November, 1985, the Boston Globe, USA, quoted a medical report by two American researchers attached to Kenya Medical Research Institute (KEMRI), Drs, Bruce Johnson and Charles Oster that, one tenth of the residents of Central and East Africa are infected by HIV/AIDS (Ibid). In what looked like strained interstate relations Mr. Simon Shitemi, Permanent Secretary in the Ministry of Health in the Kenya government told Reuters:

There is an element of racism in all this. AIDS surfaced in the USA but now they are saying there is an African AIDS if the source of AIDS was Africa and one- 
tenth of the population are infected, why are Africans not dying in large numbers, such as is being experienced elsewhere? (ibid: 14).

The HIV/AIDS pandemic drew more and more states into the debate. On 21 November 1985, Peter Nyakiamo, Minister for Health in Kenya, told parliament that eight people in Kenya had died of AIDS, four of them Kenyans and four foreigners: two Ugandans, one Rwandese and one Tanzanian. On the suspect list were fourteen people who included six Kenyans, two Ugandans, one Burundian, one Rwandese, one Finn, one Israel, and one Sudanese (Ibid). Nyakiamo assured parliament that AIDS compared with malaria and tuberculosis posed significantly a problem (ibid). However, the vagueness or even the silence about the statistics was part of the government diplomatic strategy of defending the country against international stigmatization. By May 1986, Kenya had recorded 28 cases of the disease, half of whom were foreigners. The government made screening of blood used for medical treatment mandatory. Local and foreign researchers got into work and Kenya started reporting regularly to WHO on the number of cases diagnosed in the country. The government carried out quite diplomacy by restricting its campaigns to workshops for health workers and statements from the Ministry of Health.

Africa's lack of facilities and funds coupled with reluctance of international pharmaceutical companies that prepared to take up markets created by rich countries to screen its blood donors. Between 1986-7 Kenya became the subject of a smear campaign by western press, particularly Britain. The AIDS- scare campaign was linked to Kenya's boycott of the Edinburg Commonwealth Games because of Britain's failure to impose economic sanctions against Pretoria regime in July 1986 (Ibid). The Kenya government saw in it deliberate diplomatic move to cripple the tourist industry and scare off foreign investment. The British government banned the five hundred soldiers of the parachute regiment who were on manourvour in Nanyuki from visiting the coast towns of Mombasa, Malindi and Nairobi (ibid). Further, the troubled political context in Kenya through the late 1980s and 1990s impacted on policy making, aid and implementation of HIV/AIDS programs. The problematic relations with the international donors meant aid was withheld.

The Minister for Foreign Affairs, Mr. Elijah Mwangale described the publicity by the British Broadcasting Corporation (BBC) and British newspapers to destroy Kenya's economy and subsequently the state (ibid). Mwangale argued that judging from WHO statistics, the west had the highest number of AIDS victims: Kenya 239, Britain 80,000, and USA 800,000, with 2000 dead (ibid). AIDS had caused a diplomatic war and strained Kenya's foreign relations. Britain on a further diplomatic onslaught against Kenya declared that HIV/AIDS would be included on the list of diseases tested/checked by the port officers to restrict entry into that country. This was not made known through diplomatic channels or public pronouncement, but Kenyans travelling for further studies were required to undergo HIV/AIDS tests to qualify for a visa /admittance. The pandemic heightened diplomatic tensions to an extent that England's Prince Charles carried his own blood supply on a trip to Kenya in 1995 (ibid).

The government in 1992 integrated Sexually Transmitted Diseases (STD) control into the AIDS control thus establishing the National AIDS and Sexually Transmitted Disease Programme (NASCOP). In 1995 the World Bank advanced a credit of \$40million from the International Development Association (IDA) for sexually transmitted infections. This was a milestone achievement from the multi-lateral diplomacy programme formulation and implementation in the fight against the pandemic (ibid). On September 25, 1997, Kenya Parliament voted unanimously in favour of Sessional Paper No. 4 of 1997 on AIDS in Kenya in the strive to control the pandemic and policy guidelines. This move attracted bilateral donors including the British who had been at loggerhead with authorities in Nairobi. 
In what looked like warming up of relations the British government through Ms. Caroline Sergeant, a senior health and population adviser, International Development granted Kenya Ksh 3billion per year for the next five years to fight the war against HIV/AIDS in Kenya. It was the duty of Kenyans and the International Community to ensure that the disease did not spread any further Ms Caroline Sergeant said (Daily Nation, 1995).

It is worth noting that in the first half of the 1990's, donor funds especially from the IMF and the WB were unavailable for social programmes due to what was seen as Nairobi's poor governance policies. However, in 1995 the Kenyan government secured a US \$40 million credit for five -year project against Sexually Transmitted Infections (STDs including AIDS). The real all-sector response was not visible until the end of 1999 when all parliamentarians, including president Moi assembled for a seminar in Mombasa to discuss HIV/AIDS as a matter of National importance. During that seminar President (RTD) Moi declared AIDS a National Disaster (Ogot, 2004).

The issue of infectious disease especially HIV/AIDS continued to attract the attention of multilateral organizations and on January 11, 2000 the UN Security Council held its first ever session dedicated to AIDS pandemic. AIDS was finally declared a security as well as a health threat. A resolution pressing for national leadership and engagement was passed. However, back home the debate on the condom use reached fever point with a plan by Condomic PLC of Germany with a joint venture with local enterprises to build a Ksh175 million condom factory in Kenya.

It was to have a capacity of 100 million condoms from the initial investment portfolio of US $\$ 2.5$ million (Ksh. 175million). The venture was to be supported by the German Development Bank (DEG) within the framework of the Public Private Partnership Programme (PPP) (ibid). The proprietors of the factory hoped to see strong quality control standards of condoms in Kenya, so as to avoid the expenses incurred in the quality testing of condoms which had to be done in Australia before being reshipped to destinations in East Africa (ibid). This project was seriously opposed by the Catholic Church, National Christian Churches of Kenya( NCCK) and the Supreme Council of Imams (SUPKEM) who argued that the nearer the condoms factory the higher the rate of promiscuity and moral decadence.

The World Bank (WB) continued to fund projects targeting grassroots communities beginning January, 2001. The US $\$ 50$ million (Ksh. 3.9 billion) project was aimed at strengthening the activities of the National AIDS Control Council which was later shifted to the Provincial, district, and later community level. The government's National AIDS Council (NACC) enjoyed significant higher funding from donors, including US $\$ 17$ million from Britain's Department for International Development (DFID), US\$15 million from the UN Development programme for the 2001-2002 financial year. UNAids, committed US\$300,000 for the establishment of National AIDS Resource Centre , The Council received US $\$ 43$ million, a quarter of the Health Ministry's annual budget for 2001-2002, from donor (East African Standard, 2000). Earlier on the in the Abuja Summit on HIV/AIDS, 2001 the governments had undertaken to spend 15 per cent of their expenditure on health. Only Zimbabwe and Tanzania had met the target and Kenya was at half the proposal (Ogot, 2004).

Management of HIV/AIDS and International trade agreements have always raised questions whether multi-national companies sale the anti-retroviral cheaper or they want to make huge profits and the role of patent laws in accessing HIV/AIDS drugs. The Trade Related Aspects of Intellectual Property Rights (TRIPS) has the greatest effect on access to the medicines. It set 
minimum standards such as 20 years patent protection limits for pharmaceuticals (The East African, 2001).

However, in certain instances, for example public health emergencies, TRIPS allowed for the production of medicines by companies other than the patent holder, called compulsory Licensing. It also allows importation of medicines from countries other than the country of manufacture, called Parallel Importing. Médecins Sans Frontières (MSF) of Belgium observed that Kenya was a very keen follower of the International Patent laws and could not manufacture patented medicines or parallel importation Médecins Sans-Frontier, Public Health experts in Kenya, AIDS activists campaigned to persuade the government to revise its patent laws to produce or access cheap, generic AIDS drugs to check HIV/AIDS scourge.

Kenya extended its patent protection from the seven years stipulated in the British Colonial law to the World Trade Organization's (WTO) twenty years. This sealed the Western pharmaceutical companies' exclusive rights to anti- retroviral treatments for several generations of AIDS patients thus directing Kenyans' foreign relations with commercial multinational interests, overriding the needs of her citizens (Sunday Standard, 2003). Parliament had on 3 May, 2001 derailed the Industrial Property Bill seeking Kenyans to access cheap antiAIDS generic drugs. The opposition then voted it into the second reading insisting it should be referred to the House Departmental Committee for perusal. Kenyan political observers argue that this action was triggered by fears that the government planned to scuttle debate on the Constitution Review (Amendment) Bill, which was a legal prerequisite to a much delayed reform that the opposition contended was a requirement for safeguarding democracy (East African Standard, 2001).

In June 2001 Kenya parliament approved the Industry Properties (IP) Bill 2001. The multinational pharmaceuticals through its Director General, Harvey Bale arrogantly declared: "From our perspective, nothing will change at all" (ibid). Furthermore, it was evident that AIDS research could not take place without consultation and guidance of the pharmaceuticals giant, through which funding was channeled. The gazzetment by Trade and Industry Minister Nicholas Biwott of Property Act (KIPA) meant that generic drugs could now be imported into the country (Ogot, 2004). The act could now be used to access drugs to treat tuberculosis, malaria, typhoid or any other infectious disease. At this point the government had realized the seriousness of this infectious disease and president (Rtd) Daniel arap Moi declared: "AIDS is not just a serious threat to our social and economic development it is a real threat to our very existence" (Sunday Standard, 2003). HIV/AIDS programme became a multi-sectoral initiative involving several ministries; it needed to be in an office with an overall coordinating responsibility. This decision was supported by the World Bank's Vice President for Africa (Sunday Standard, 2003).

In 2002 a conference was held in Eldoret by the East African medical fraternity and some of the issues raised were how to fight against infectious diseases. They were representatives of Uganda Medical Association, Kenya Medical and Dentists Board and the Tanzanian Medical Association. It was observed that there is a noticeable rise in the prevalence of both infectious and non-infectious disease in the region (Daily Nation, 2002). At the conference doctors from Kenya and Uganda differed on how to go about in sensitizing the people on HIV/AIDS. Uganda Medical Association Secretary General Myers Lugemwa sparked of the debate when he called for the preaching of the pandemic in public service vehicles, barazas (public meetings) and other meetings, "just as pastors preach Jesus". He further argued that widespread distribution of condoms and compulsory sex education in schools in Uganda had helped in the drop of 
prevalence of the infection. Some Kenyan doctors disagreed, saying this would reduce moral will power to resist sex. They emphasized abstinence (Daily Nation, 2001).

A regional initiative at an inter-ministerial level was held on $4^{\text {th }}$ September 2002. The launch was attended by ministers from the three East African countries and was dubbed "Celebrate Life Initiative". The launch targeted the youth and was deemed to mark the beginning of concerted efforts against infectious diseases. The Kenya Health minister on the same occasion received free antiretroviral drugs for the management of HIV infected pregnant mothers and newborn babies, from Boehringer, Ingelheim, which is said to have come barely a month after the government announced the commencement date for the Industrial Property Act (IPA). The act enabled the country to access cheaper generic AIDS drugs from international market which was expected to save lives of 500,000 babies born to HIV positive mothers. The Act (IPA) also made allowance for a way to widen access to essential medicines through innovative sourcing and local production. The key among these is parallel importation which lays down the legal framework for licensed importer to shop around the world for cheapest medicine, regardless of patent rights, so that low prices can be passed on to the patient (Daily Nation, 2002).

In HIV/AIDS (Human Immune Deficiency Syndrome) was first diagnosed in 1984. Kenya is one of the beneficiaries of Africa Unite Globally (AUAAG), which is an organization established by African-Americans for the purpose of assisting in the fight, to alleviate the suffering of people infected with HIV/AIDS virus around the world, and helps prevent future outbreaks. Professor Sam Ongeri the then Minister for Health attended a conference on the 16 December 2001, dubbed "Our Communities Fight Back" at St Louis Missouri in the USA. As a result of this conference, it was resolved that American Musicians should come and fight HIV/AIDS in Sub Sahara African, to which they came to Kenya in the year 2002. AUUG has been working in collaboration with the Ministry of Health in Kenya. A mass communication campaign had been running and cumulated into a major music concert on $8^{\text {th }}$ October 2002, at Uhuru Park in Nairobi, performed by both local and international artists (Sunday Nation, 2002). The international community has been important in driving the national agenda on HIV/AIDS. The international community has been in the forefront in supporting research initiatives at various points from the 1980s.

\section{CONCLUSION}

In recent years, emerging and re-emerging infectious diseases have captured increased attention internationally. Infectious diseases have emerged as a field of inquiry in the areas of public health, science, and politics. This paper discussed the impact of infectious diseases on Kenya's foreign relations and diplomacy. It argued that infectious diseases are always crossborder and of both national and international concern since they touch on states national interests and security. The paper analyzed measures that have been taken to manage these communicable diseases by the government and its institutions. Furthermore, this paper illustrated how national policies interact with international and multinational conventions to influence foreign relations and diplomacy of a state like Kenya.

Controlling emerging and reemerging infectious diseases can require extreme actions and coordination between many national and international actors making the ability to respond a reflection of the capacity of a governing system. It is worth noting that with global pandemic of infectious diseases and a host of many other health challenges, diseases will remain salient in the conduct of international relations. Thus, addressing the concerns and challenges raised by infectious disease requires that we analyze them as a matter of international relations. Cooperation on infectious disease control could be very fruitful among states, however, this is 
only possible if national interests converge and remain converged. There is a clear role of disease in shaping foreign policy.

\section{References}

African Union. (2012). Roadmap on Shared Responsibility and Global Solidarity for AIDS, TB and Malaria Response in Africa, http://www.au.int[1] pdf. Accessed 22.6.2013.

Anonymous (2020: Jan., 31). Coronavirus spreads to more countries: All the latest updates: United Kingdom and Russia are latest countries to confirm cases, as number of people infected in China nears 10,000. Aljazeera.

Arai-Takahashi, Y. (2001). The role of international health law and WHO in the regulation of public health: In: Martin R, Johnson L, eds. Law and Public Dimension of Health (pp.113-141). London: Cavendish Publishing Ltd.

Buzan, B. (1991). People, State, and Fear: An Agenda for International Security Studies in Post- Cold War Era. Boulder: Lynne Rienner.

Daily Nation (2002). May 30.

Daily Nation (2002). November 8.

Daily Nation (2009) August 29.

Daily Nation. (2002). April 25.

Daily Nation. (2002). October 3.

Daily Nation. (1995). May 8.

Daily Nation. (2001). November 15.

Daily Nation. (2002). June 13.

Dorolle, P. (1969). Old Plagues in the Jet Age: International Aspects of Present and Future Control of Communicable Diseases. Chronicles of the World Health Organization, 23, pp. 103-11.

East African Standard (2000). February 12.

East African Standard. (2001). November 26.

East African Standard. (2004). August 31.

Fidler, D. P. (1997). The Globalization of Public Health: Emerging Infectious Diseases and International Relations. Indiana Journal of Global Legal Studies. Vol.5, Issue 1, article 2. http://www.repository.law.indiana.edu/ijgs. Accessed 11.4.2013.

. (1998). Microbialpolitik: Infectious Diseases and International Relations. American University International Law Review, vol. 14, Issue 1, pp. 1-53.

(2001). The Globalization of Public Health: The first 100 years of international health diplomacy. Bull World Health Organ (online), vol. 79, no.9. htt://www.sce/osp.org/10.1590/50042-96862000900009.

. (2002). Emerging Trends in International Law Concerning Global Infectious Disease Control, http://wwwnc.cdc.gov/eid/article/9/3/02-0336_article.htm, 28- Apr-13.

(2003). SARS: Political pathology of the first post-Westphalian pathogen. J Law Med Ethics, 31, 485-505.

Gathura, Gatonye (2020a). Vital Malaria Vaccine Trial to Cost State 3.7 Billion. The Standard, January 11.

Gathura, Gatonye (2020b). Cholera, Measles Continue to Ravage Kenyan's in New Year as Control Efforts Fails. The Standard, January 11.

Garret, L. (1994). The Coming Plague: Newly Emerging Diseases in a World Out of Balance. New York: Farrar, Straus and Giroux.

(1996). Return of Infectious Diseases. Foreign Affairs, January- February, 1996.

Grad, F.P. (2002). The preamble of the constitution of the World Health Organization. Bull. World Health Organ, 80, 981-982.

Heymann, D.L. \& Rodier, G. (2004). SARS: A Global Response to an International Threat. The Journal of World Affairs, vol. 10, issue 2 .

Heymann, D.L. (2005). Emerging and re-emerging infectious diseases from Plague and Cholera to Ebola and AIDS: a potential for international spread that transcends the defences of any single country. Journal of Contingencies 
and Crisis Management. Review of A.T. Price- Smith, ed., Plagues and Politics: Infectious Disease and International Policy. Palgrave Macmillan, 2001; B.A. Whiteside, ed., AIDS in the Twenty - First Century: Disease and Globalization, Palgrave Macmillan, 2000.Accessed 5.5.2013.

\section{Affairs.} (Summer/ Fall, 2001). The Fall and Rise of Infectious Diseases. Georgetown Journal of International

Kirkpatrick, T.J. (2020: Jan.). As Virus Spreads, U.S. Temporarily Bars Foreigners Who've Visited China. The New York Times.

Klempner, MS., \& Shapiro, D.S., (2004). Crossing the species barrier: one small step to man, one giant leap to mankind. New England Journal of Medicine, 350:1171-1172. League of Nations Covenant. (1923).

Lewis, M. (Summer/ Fall, 2001). The Economics of Epidemics. Georgetown Journal of International Affairs.

Merab, Elizabeth (2020: Jan.,27). Kenya warns against travel to China over deadly coronavirus. Daily Nation.

Meyer, J. (2006). Appendix C. Changing Vector Ecologies: Political Geographic Perspectives. The Impact of Globalization on Infectious Diseases Emergence and Control: Exploring the Consequences and opportunities. Workshop Summary- Forum on Microbial Threats, National Academies Press.

http://www.nap.edu/openbook.php?record id=11588 page=197. Accessed 5.5.2013.

Mumbere, Daniel (2020: Jan.). Coronavirus: Negative cases across Africa; Uganda, Zimbabwe quarantine 100s. Africa News.

Nakajima, H. (1997). Global Disease Threats and Foreign Policy. The Brown Journal of World Affairs, Vol. 4, No. 1.

Nelson, S.H. (2002). The West's Moral Obligation to Assist Developing Nations in the Fight Against HIV/AIDS. Health Care Analysis, March, pp. 87-108.

Nieto, A. (2005). An International Institutionalist Approach to the Globalization of Emerging Infectious Diseases. Masters of Arts in Law and Diplomacy Thesis, Fletchers School, Tufts University.

Ogot, B.A. (2004). Politics and the AIDS Epidemic in Kenya 1983-2003. Kisumu: Anyange Press Ltd.

Prescott, E.M. (January, 2007). The Politics of Diseases: Governance and Emerging Infections. Global Health Governance, vol.1, no. 1, http://www/ghgj.org, accessed 5.5.2013.

Price- Smith, A.T. (1999). Ghosts of Kigali: Infectious Disease and Global Stability at the turn of the Century. Jstor: International Journal, vol. 54, no. 3.

(2001). The Health of Nations: Infectious Disease, Environmental Change and Their Effects on National Security and development. Cambridge, MA: MIT, Press.

(2002). Plagues and Politics: Infectious Diseases and Globalization. Palgrave Macmillan.

Republic of Kenya. (1970) Public Health, CAP. 242.

Sunday Nation. (2002). October 6.

Sunday Standard. (2003). February 9.

Sunday Standard. (2003). February 9.

Taylor, AL, Bettcher DW, Fluss SS, et al. (2002). International health instruments: An overview. In: Detels R, ed. Oxford Textbooks of Public Health (pp.359-86). Oxford: Oxford University Press.

Taylor, A. (1996). Controlling the Spread of Infectious Diseases: Towards a Reinforced Role for the International Health Regulations, Oxford Univ. Press.

The East African, May 11-17, 2009, 18.

The East African. (2002). 12-18.

Thomas, N. and Tow, T. (2002). The Utility of Human Security: Sovereignty and Humanitarian Intervention. Security Dialogue, June, pp. 177-192.

UNICEF, UNDP, WB, WHO. (2004). Special Programme for Research and Training in Tropical Diseases (TDR), Globalization and Infectious Diseases: A Review of the Linkages, Special Topics.

Willets, P. (1997). Transnational actors and international organizations in global politics. In Smith, S, Baylis, J., eds., The Globalization of World Politics. Oxford: Oxford University Press. 
Wilson, M.E. (1995). Travel and the Emergence of Infectious Diseases, 1 EMERGING INFECTIOUS DISEASES 39 (Apr- June).

World Health Organization Basic Documents. (2003). 44th ed. Geneva, Switzerland: World Health Organization.

World Health Organization Report. (1996). Fighting Disease, Fostering Development. Infectious Diseases htt://www.who.int/topics/infectious_diseases/en/ Accessed 4.5.2013.

World Health Organization. (2002). Global Crisis-Global Solutions: Managing Public Health Emergencies of International concern through the Revised International Health Regulations. Geneva, Switzerland: World Health Organization. WHO/CDS/CSR/GAR/2002.4.

Youde, J. (2005). Enter the Fourth Horseman: Health Security and International Relations Theory. The Whitehead Journal of Diplomacy and International Relations. Winter/ Spring, 193-208. 